\title{
No-till and cover crops shift soil microbial abundance and diversity in Laos tropical grasslands
}

\author{
Pascal Lienhard • Florent Tivet • André Chabanne • \\ Samuel Dequiedt • Mélanie Lelièvre • \\ Sengphanh Sayphoummie • Bounma Leudphanane • \\ Nicolas Chemidlin Prévost-Bouré • Lucien Séguy • \\ Pierre-Alain Maron • Lionel Ranjard
}

Accepted: 10 May 2012 /Published online: 22 June 2012

(C) The Author(s) 2012. This article is published with open access at Springerlink.com

\begin{abstract}
Agricultural practices affect the physical and chemical characteristics of the soil, which in turn may influence soil microorganisms with consequences on soil biological functioning. However, there is little knowledge on the interactions between agricultural management, soil physicochemical properties, and soil microbial communities, notably in tropical ecosystems with few studies conducted in strongly weathered and acid soils. Here, we investigated the early effect of tillage and crop residues management on top soil physical, chemical, and microbial properties in an acid savannah grassland of northeastern Laos. We initiated a 3-year rotation of rice/corn/ soybean under three no-till systems (NTs) distinguished by the cover crops associated prior to and with the main crops, and
\end{abstract}

P. Lienhard $\cdot$ F. Tivet $\cdot$ A. Chabanne $\cdot$ L. Séguy

CIRAD, UR SIA,

F-34398 Montpellier Cedex 5, France

P. Lienhard $\cdot$ F. Tivet

NAFRI, NCAC,

PO Box 7170, Vientiane, Lao Peoples Democratic Republic

P. Lienhard $\cdot \mathrm{S}$. Dequiedt $\cdot$ M. Lelièvre $\cdot$ N. C. Prévost-Bouré

P.-A. Maron $\cdot$ L. Ranjard

INRA, UMR1347 Agroécologie,

BP 86510, F-21000 Dijon, France

S. Dequiedt $\cdot$ M. Lelièvre $\cdot$ P.-A. Maron $\cdot$ L. Ranjard $(\triangle)$

INRA, Plateforme GenoSol, UMR1347 Agroécologie,

BP 86510, F-21000 Dijon, France

e-mail: Lionel.Ranjard@dijon.inra.fr

S. Sayphoummie $\cdot$ B. Leudphanane

PROSA/MAF,

PO Box 10118, Vientiane, Lao Peoples Democratic Republic

N. C. Prévost-Bouré

AgroSup, UMR1347 Agroécologie,

BP 86510, F-21000 Dijon, France one conventional tillage-based system (CT). The effect of agricultural management was evaluated 2 years after land reclamation in reference to the surrounding natural pasture (PAS). Our results demonstrate that NTs improve soil physicochemical characteristics (aggregate stability, organic carbon, and cation exchange capacity) as well as microbial abundance (total biomass, bacterial and fungal densities). A significant discrimination of the genetic structure of soil bacterial community was also observed between NTs, CT, and PAS. Interestingly, bacterial abundance and diversity were differently influenced by soil environment changes: microbial density was affected by the quantity and diversity of crop residues, soil organic carbon, and exchangeable base contents, whereas soil bacterial genetic structure was mainly determined by exchangeable aluminum content, $\mathrm{pH}$, cation exchange capacity, and $\mathrm{C} / \mathrm{N}$ ratio. Altogether, our study represents one of the most complete environmental evaluations of agricultural practices in tropical agrosystems and leads to recommend no-till systems with high residue restitutions to improve the physical, chemical, and microbial properties of tropical acid soils and thus contribute to the sustainability of agriculture in these ecosystems.

Keywords Tropical soil · Microbial community · Tillage · Conservation agriculture $\cdot$ Cover crop

\section{Introduction}

Soil microbial communities are responsible for a wide range of soil functions and ecological services, such as soil structure maintenance, organic matter turnover, and nutrient cycling (Dick 1992; Kladivko 2001). Among human activities, agricultural practices affect the physical and chemical 
characteristics of the soil in which microorganisms live, thereby affecting their abundance, diversity, and activity (Dick 1992; Kladivko 2001; Bunemann et al. 2006; Nicolardot et al. 2007; Pascault et al. 2010). External agricultural inputs such as organic amendments (animal or green manure), mineral fertilizers, and pesticides affect in different ways soil microorganisms (Dick 1992; Bunemann et al. 2006). Crop rotation and plant diversity are also important to maintain soil microbial diversity and activity (Nicolardot et al. 2007; Pascault et al. 2010). In conventional agriculture, tillage has generally the greatest impact on biological properties since physical disturbance changes soil water content, temperature, aeration, and the degree of mixing of crop residues within the soil matrix (Dick 1992; Buckley and Schmidt 2001; Kladivko 2001). Tillage also reduces soil macroaggregate content which provides an important microhabitat for microbial density, diversity, and activity (Ranjard and Richaume 2001; Six et al. 2002). In addition, tilling tools disturb fungal hyphal growth at soil surface leading to a reduction of their relative abundance in the soil (Frey et al. 1999; Balesdent et al. 2000).

Based on the principle of minimal soil disturbance, no-till (NT) farming systems have been widely adopted in large-scale mechanized agriculture to prevent soil erosion and decrease production costs (Derpsch et al. 2010). Combined with maximal soil cover (mulch) and diversified crop sequences, NT systems have demonstrated in addition to have a positive impact on soil physical and chemical properties (Castro Filho et al. 2002; Six et al. 2002; Séguy et al. 2006; Lal 2008), and on soil microbial biomass and activity (Kladivko 2001; Kaschuk et al. 2010; Sapkota et al. 2011). However, the adoption of notill systems in small-scale agriculture is still low (Derpsch et al. 2010) with therefore little data available regarding their environmental impact on soils, notably in tropical grassland ecosystems, whereas the expansion of agriculture is a key challenge in these areas to increase and sustain food production (Lal 2008). If the acid savannah grasslands of the world encompass vast areas of potentially arable land, they are however mostly considered marginal because of low inherent fertility and susceptibility to rapid degradation (IAEA 2000).

In addition, little is known about the impact of agricultural practices on soil microbial communities in tropical agrosystems, and their role in soil biological functioning. The recent development of culture-independent molecular tools based on soil DNA extraction and characterization and of in silico meta-analysis have enabled the systematic analysis of soil microbiota leading to a better understanding of the ecological impact of land use management (Maron et al. 2011). Despite these advances, the links between microbial communities and soil physicochemical properties as affected by agricultural practices are still a major challenge and especially in tropical ecosystems where no-till farming systems become an innovative and recurrent way of crop production.
In this context, our objective was to investigate the early effect of tillage systems and crop residue management on top soil physical, chemical, and microbial properties in an acid tropical grassland ecosystem located in the western part of Xieng Khouang province, northeastern Laos. For this purpose, we initiated in 2008 a 3-year rotation of rice (Oryza sativa L.), corn (Zea mays L.), and soybean (Glycine max (L.) (Merr.) conducted under three no-till systems (NTs) distinguished by the cover crops associated prior to and with the main crops, and one conventional tillage-based system (CT) based on soil plowing with disks and on the burying of crop residues. The impact of agricultural systems was evaluated 2 years after land reclamation in reference to the surrounding natural pasture (PAS). Molecular tools such as soil DNA concentration and real-time quantitative PCR of bacteria and fungi were used as bioindicators to evaluate the effect of agricultural practices on soil microbial abundance (Dequiedt et al. 2011; Smith and Osborn 2009; Chemidlin Prevost-Boure et al. 2011). The genotyping of the soil bacterial community structure was assessed by a DNA fingerprinting approach, the automated ribosomal intergenic spacer analysis technique, that has been demonstrated to be sensitive and relevant for evaluating modifications in microbial community composition consecutive to land use management changes (Pascault et al. 2010; Lejon et al. 2007). The relationships between the soil physicochemical properties and the abundance and diversity of soil microbial communities were statistically tested to deduce an early environmental evaluation of these cropping systems.

\section{Material and methods}

\subsection{Experimental site}

The study was conducted in Poa village (Lat. $19^{\circ} 33^{\prime} \mathrm{N}$, Long. $\left.102^{\circ} 59^{\prime} \mathrm{E}\right)$ at $1,130 \mathrm{~m}$ AMSL. The climate is both tropical and mountainous with a 6-month (April-September) wet and hot season and a 6-month dry season including 3 months of cold (December-February). The mean annual precipitation is $1,400 \mathrm{~mm}$. The soils at the site are red Oxisols with clay content decreasing gradually from the upper part (clayey soils, USDA classification) to the lower part (sandy-loamy soils) of the site. The 3-year rotation was conducted in a split-split plot experimental design combining three factors (Fig. 1) with three replications of $270 \mathrm{~m}^{2}$ each for a total of 108 sub-sub-plots.

For the present study, we limited our sampling to the upper part of the site (clay dominant soils, total of 12 independent replicates per tillage system, in white font in Fig. 1) since previous studies have shown soil texture as a major factor in explaining soil microbial diversity distribution (Martiny et al. 2006; Dequiedt et al. 2011). We thus decided to minimize the influence of this factor in order to 


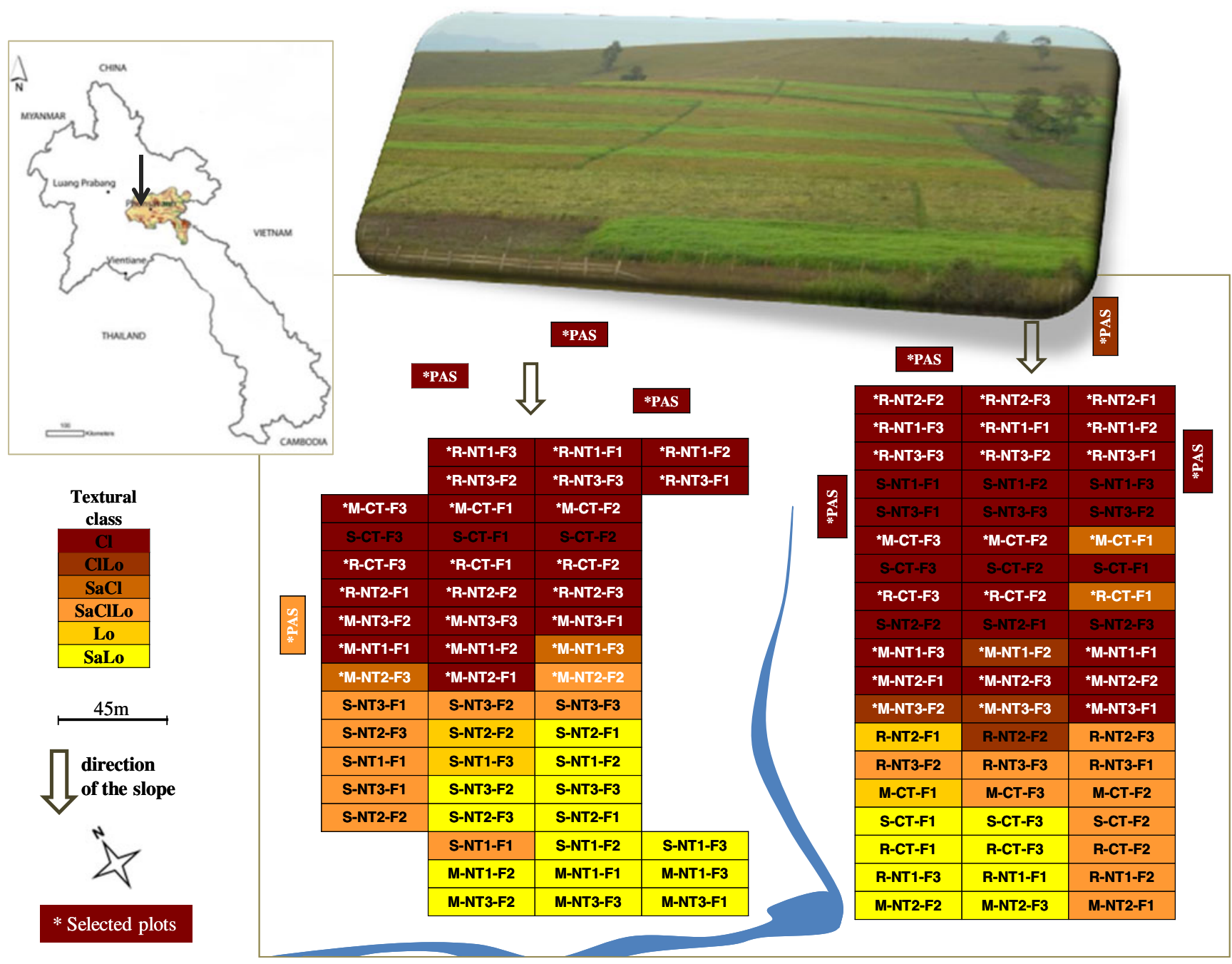

Fig. 1 Experimental design. Starting crops in 2008 (three modalities): $R$ rice variety Sebota1; $M$ maize hybrid LVN10; $S$ soybean variety Asca. Cropping systems (four modalities): $C T$ conventional tillage based on annual soil plowing with disks and burying of former crop residues; $N T$ (1, 2, and 3), no-till systems with cover crops: finger millet (Eleusine coracana Gaern) and pigeon pea (Cajanus cajan) associated prior to and with maize in NT1; finger millet and stylo (Stylosanthes guianensis cv. CIAT 184) associated prior to and with maize in NT2; ruzi grass (Brachiaria ruziziensis cv. ruzi) and pigeon pea associated prior to and with maize in NT3; stylo associated with rice in all NT treatments; oat (Avena sativa L.)

highlight the differences related to agricultural management. The natural surrounding pastureland (PAS) was taken as reference treatment (eight replicates).

\subsection{Estimations of stubble restitutions}

We used the cumulated amount of stubble returns as a quantitative indicator of organic inputs, and the percentage of broad-leaf species in crop residues returns as a qualitative indicator of organic inputs (Table 1). Stubble production, including associated crop and weed contributions, were and buckwheat (Fagopyrum esculentum Moench) in succession of soybean in all NT treatments. Fertilization (three modalities): FI $60-80-60 \mathrm{~kg} \mathrm{ha}^{-1}$ year ${ }^{-1}$ of $\mathrm{N}-\mathrm{P}_{2} \mathrm{O}_{5}-\mathrm{K}_{2} \mathrm{O}$ (N limited to $32 \mathrm{~kg} \mathrm{ha}^{-1}$ for soybean); F2 120-160-120 kg ha ${ }^{-1}$ year $^{-1}$ of $\mathrm{N}-\mathrm{P}_{2} \mathrm{O}_{5}-\mathrm{K}_{2} \mathrm{O}$ (N limited to $32 \mathrm{~kg} \mathrm{ha}^{-1}$ for soybean); F3 F2 during the first 2 years, $\mathrm{F} 1$ after that; $\mathrm{N}$ coming from urea $(46 \% \mathrm{~N}), \mathrm{P}_{2} \mathrm{O}_{5}$ from thermo phosphate $\left(16 \% \mathrm{P}_{2} \mathrm{O}_{5}, 28 \% \mathrm{CaO}\right.$, and $\left.18 \% \mathrm{MgO}\right)$, and $\mathrm{K}_{2} \mathrm{O}$ from $\mathrm{KCl}\left(60 \% \mathrm{~K}_{2} \mathrm{O}\right)$. In addition, all agricultural treatments received an initial application of $2 \mathrm{Mg} \mathrm{ha}^{-1}$ of locally produced lime $(27 \%$ of $\mathrm{CaO})$. PAS surrounding natural pasture taken as reference treatment. Asterisks treatments selected for the study

estimated twice a year: at main crop harvests and before land preparation. Measures were made in each plot on six subplots of $4 \mathrm{~m}^{2}$ each randomly chosen. A random lump crop residue sample of $2 \mathrm{~kg}$ was taken from the six subplots to determine dry biomass. Grain yields were measured on each total plot area $\left(270 \mathrm{~m}^{2}\right)$.

\subsection{Soil sampling}

The soil was sampled at $0-10-\mathrm{cm}$ depth, in June 2009, during the second year of the rotational sequence. For soil 


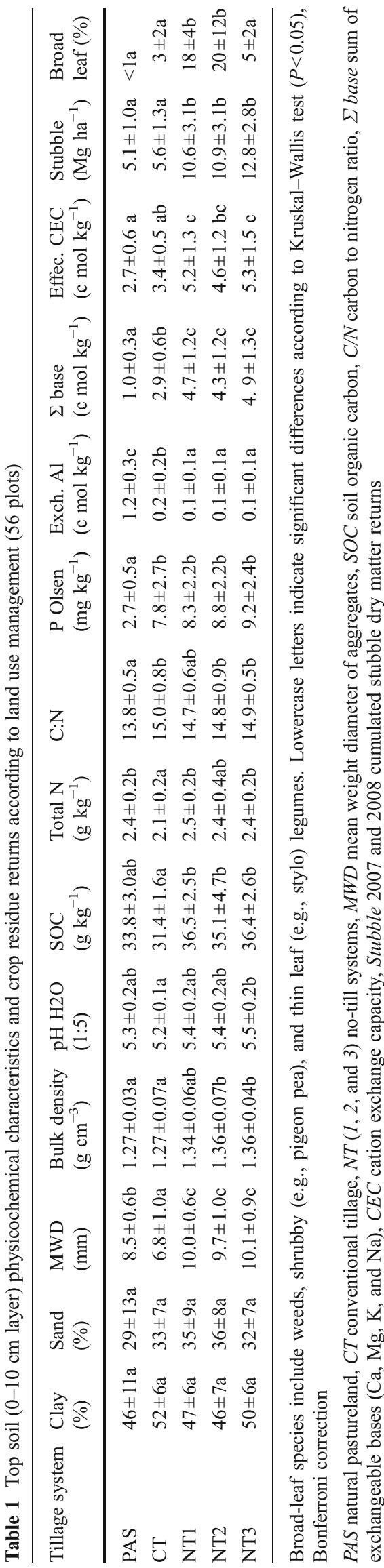

chemical and microbial analysis, a composite sample was made of a pool of five subsamples taken in the diagonal of the plot $(50 \mathrm{~m})$. For soil bulk density and soil aggregate stability determination, randomized triplicates were taken for each plot (total of 36 independent replicates per cropping system and 24 replicates for the natural pastureland).

\subsection{Soil physical and chemical analysis}

We used the mean weight diameter (MWD) of aggregates as an indicator of soil aggregate stability. Aggregate size classes were separated by wet sieving, following a procedure described by Castro Filho et al. (2002). Briefly, soil samples were passed through a $19-\mathrm{mm}$ mesh sieve, and clods $>19 \mathrm{~mm}$ were softly broken along their natural cleavage planes and were stored in polystyrene boxes to prevent moisture loss and excessive drying. Samples were then wet-sieved in laboratory through a series of six sieves $(8$, $4,2,1,0.5$, and $0.25 \mathrm{~mm}$ ). Aggregate separation was achieved by agitation $(3.5 \mathrm{~cm}$ amplitude, 30 rotations per minute for $10 \mathrm{~min}$ ). MWD was calculated as follows:

$$
\mathrm{MWD}=\sum_{i=1}^{n} x_{i} w_{i} \text { where } W_{i} \text { is the relative weight of each }
$$
aggregate class in relation to the whole and $X_{i}$ is the mean diameter of the considered class (millimeters).

The soil bulk density $\left(\rho_{\mathrm{b}}\right)$ was used as an indicator of soil porosity and measured on oven-dried $\left(24 \mathrm{~h}, 105^{\circ} \mathrm{C}\right)$ undisturbed soil samples by using a $94-\mathrm{cm}^{3}$ density cylinder.

All soil chemical analyses were done by the CIRAD laboratory in Montpellier, France. Soil organic carbon $(\mathrm{SOC})$ and total nitrogen $(\mathrm{N})$ were used as indicators of soil organic status and quantified by dry combustion. Soil $\mathrm{pH}$ (1:5 soil/water slurry), available phosphorus (P) (Olsen method), cation exchange capacity (CEC) (cobalt hexamine chloride reagent), sum of exchangeable bases $(\mathrm{Ca}, \mathrm{Mg}, \mathrm{K}$, and $\mathrm{Na}$ ) and exchangeable aluminum (Al) were used as indicators of soil acid-base and nutrient status.

\subsection{Soil molecular microbial abundance analysis}

We used soil crude DNA concentrations as estimates of microbial biomass since a highly positive linear relationship has been shown between soil DNA recovery and C-biomass measurement, this latter being indicative of the size of microbial biomass (Marstorp et al. 2000; Dequiedt et al. 2011). Soil microbial DNA was extracted and estimated on $2 \mathrm{~g}$ (dry weight) of soil using a single procedure developed by Ranjard et al. (2003) and recently optimized and standardized by the GenoSol platform (INRA, Dijon, France). DNA concentrations of crude extracts were determined by electrophoresis in a $1 \%$ agarose gel using a calf thymus DNA standard curve.

We estimated fungal and bacterial densities by realtime quantitative polymerase chain reaction (qPCR) of 
ribosomal DNA (rDNA). This approach has recently become a valuable, accurate, and culture-independent molecular tool for quantifying soil bacterial and fungal abundance (Smith and Osborn 2009; Chemidlin PrevostBoure et al. 2011). We amplified 18S rDNA sequences, which are specific to fungi, on $2.5 \mathrm{ng}$ purified soil DNA using FR1 and FF390 primers and qPCR mix $\mathrm{SYBr}^{\circledR}$ Green as described by Chemidlin PrevostBoure et al. (2011)). For bacteria, we amplified a 16S rDNA sequence using primers $341 \mathrm{~F}$ and $515 \mathrm{R}$ and $2 \mathrm{ng}$ purified soil DNA, as suggested by Smith and Osborn (2009). Real-time qPCRs were performed using the Gene Amp PCR System 9700 (Applied Biosystems ${ }^{\circledR}$ ).

\subsection{Soil bacterial community genetic structure analysis}

The bacterial community structure was assessed using the Bacterial Automated Ribosomal Intergenic Spacer Analysis (B-ARISA) method (Ranjard et al. 2003). Briefly, $12.5 \mathrm{ng}$ of DNA was used as a template to amplify the bacterial ribosomal intergenic spacer by PCR. PCR products were purified using the MinElute Kit (Qiagen ${ }^{\circledR}$ ) and quantified using Smart Ladder (Eurogentec $\left.^{\circledR}\right)$. PCR fragments were resolved on a LiCor $^{\circledR}$ DNA sequencer (ScienceTec) under denaturing conditions as described in Lejon et al. (2007). Profiles were analyzed using the 1D-Scan ${ }^{\circledR}$ software (ScienceTec), converting fluorescence data into electrophoregrams, where peaks represented PCR fragments and the height of the peaks the relative proportion of the fragments in the total products. Lengths (in base pairs) were calculated by using a size standard with bands ranging from 200 to $1659 \mathrm{bp}$.

\subsection{Statistics}

The effect of land use management on quantitative parameters was tested by the nonparametric Kruskal-Wallis test performed under XLSTAT software (Addinsoft ${ }^{\circledR}$ ). Differences between means were tested by paired multiple comparison with Bonferroni correction $(P<0.05)$. Microbial genetic structure data obtained from the 1D-Scan software were converted into a table summarizing the band presence (i.e., peak) and intensity (i.e., height or area of peak) using the PrepRISA software (Ranjard et al. 2003) under R free software version 2.10.1. Principal component analysis (PCA), between-group analysis, and coinertia analysis were performed using the ADE-4 software (Thioulouse et al. 1997) under $R$ software and provided an ordination of data in factorial maps based on the scores of the first two principal components. Monte Carlo tests were performed with 1,000 permutations to confirm the significance of the discriminated clusters.

\section{Results and discussion}

3.1 Early effect on top soil physicochemical characteristics

After 2 years of native grassland conversion to agriculture, we observed significant modifications of top soil physical and chemical characteristics. Soil aggregate stability decreased (MWD in Table 1) along the gradient NTs > PAS $>\mathrm{CT}$ and was positively correlated with the total amount of stubble restituted, SOC, total soil nitrogen, and fungal and bacterial densities (Fig. 2). Our results highlight the role of fresh plant and root-derived residues, SOC, and microbialbinding agents (e.g., fungal hyphae and polysaccharides) in enmeshing soil particles, in concordance with other studies (Six et al. 2002). Contrary to Bossuyt et al. (2001), we found that the diversity of residues also influenced macroaggregation positively with significant correlations between the mean weight diameter of aggregates and the percentage of broad-leaf species in stubble restitutions (Fig. 2). In addition, the macroaggregate disruption process observed under CT, with aggregate size values decreased by $19 \%$ compared to PAS (Table 1), might be mostly related to the direct action of tilling tools, the aggregates being submitted to compressive and shearing forces during tillage (Balesdent et al. 2000; Six et al. 2002).

Early modifications of top soil porosity were also observed, with higher bulk density values under NT compared to PAS (Table 1) which might be related to the compacting effect of agricultural equipment occurring during crop rolling and sowing operations. This compacting effect was not observed under CT due to the annual tillage which induced soil mechanical fragmentation.

Regarding top soil organic status, a significant decrease of SOC content along the gradient NTs $\geq$ PAS $>$ CT (Table 1) was classically recorded. SOC was positively and highly correlated with soil total nitrogen $(\mathrm{N})$ content, the total amount of stubble returns, the percentage of broad-leaf species in restitutions, and the aggregates' stability (Fig. 2). As for organic status, early modifications of soil acid-base and mineral nutrient status were also observed, with a positive impact of inorganic fertilizer use on soil nutrient availability in cropping system. Indeed, all cultivated treatments showed significant increases in CEC, total exchangeable bases, and available phosphorus (P), as well as a related decrease in exchangeable $\mathrm{Al}$ content (Table 1). The comparative analysis of the cropping systems, however, appeared in favor of NTs, with 1.5-fold higher exchangeable bases and CEC content under NTs than under CT (Table 1).

Altogether, the evaluation of the impact of agricultural systems on top soil physicochemical parameters highlighted early but classical modifications in favor of no-till systems which induced a significant increase of top soil aggregate stability and SOC content, and higher nutrients availability. 


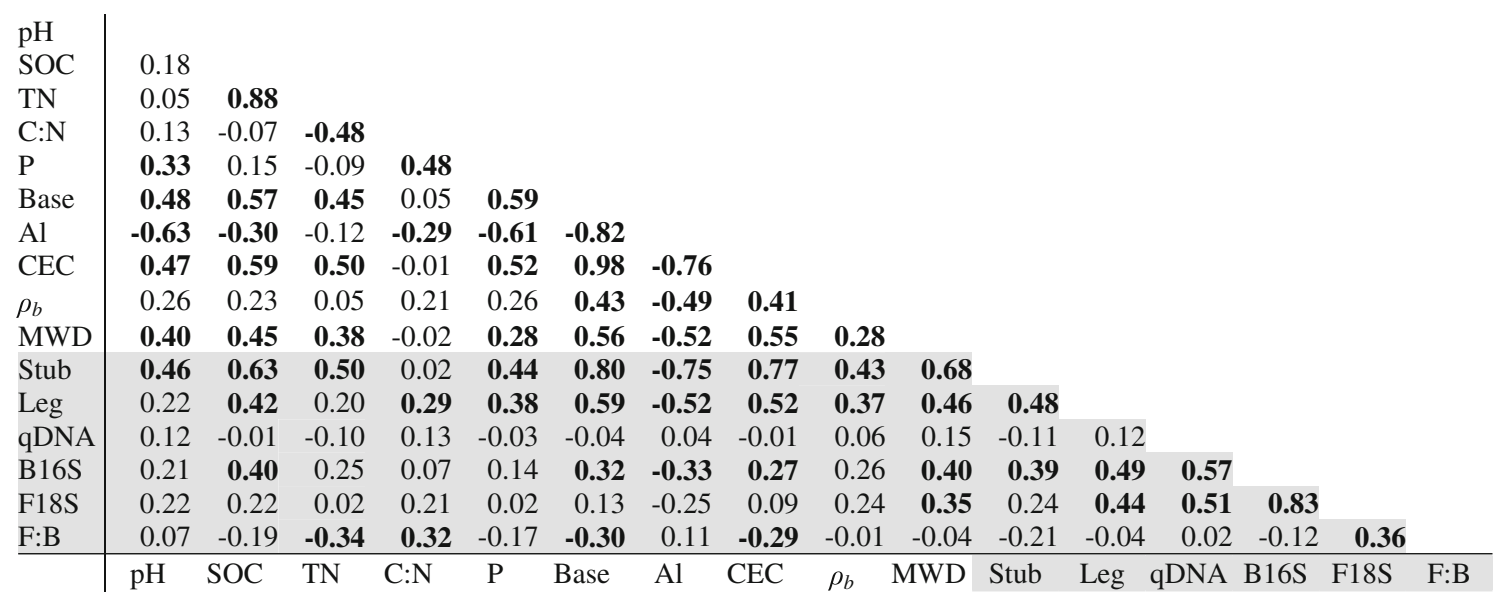

Fig. 2 Correlation matrix (Spearman) of the PCA performed on soil physicochemical parameters. Land use management impacts on organic input and microbial abundance variables were added as additive variables (in gray). Values in bold are significantly different from 0 at $P<0.05$ (52 plots). SOC soil organic carbon, $T N$ total nitrogen, $C: N$ carbon to nitrogen ratio, $P$ available phosphorus, Base sum of exchangeable bases, $A l$ exchangeable aluminum, $C E C$ cation exchange capacity, $\rho_{b}$ bulk density, $M W D$ mean weight diameter, Stub total amount of stubble returns, Leg percentage of broad-leaf species in Stub, $q D N A$ molecular microbial biomass, $B 16 S$ molecular bacterial density, $F 18 S$ molecular fungal density, $F: B$ fungal to bacterial ratio
However, these early changes did not impact soil productivity with similar crop growth and grain yields observed in 2008 (data not shown), this latter being certainly related to good physical (aggregate stability) and organic (SOC content) characteristics of soils before land reclamation as estimated by the natural pasture characteristics and by the limited time of cultivation at evaluation ( 2 years).

\subsection{Early effect on soil microbial abundance}

DNA yields, which were used as estimates of microbial biomass, decreased similarly along the gradient NT1 (mean value of $16.6 \mu \mathrm{g}$ of DNA g ${ }^{-1}$ of soil) $>$ NT2, NT3, and PAS $>$ CT $(11.9 \mu \mathrm{g}$; Fig. 3a). No significant correlation could be established between soil physicochemical parameters and molecular biomass (Fig. 2). This could be related to the high variability observed within replicates regarding physicochemical and textural characteristics (see standard deviations in Table 1), and microbial biomass (Fig. 3a), which makes the significant discrimination between treatments difficult. This could also be linked to a low sensitivity of the method when confronted with the limited amplitude of soil physicochemical variations in relation with the limited time of cultivation ( 2 years). Indeed, in more contrasted
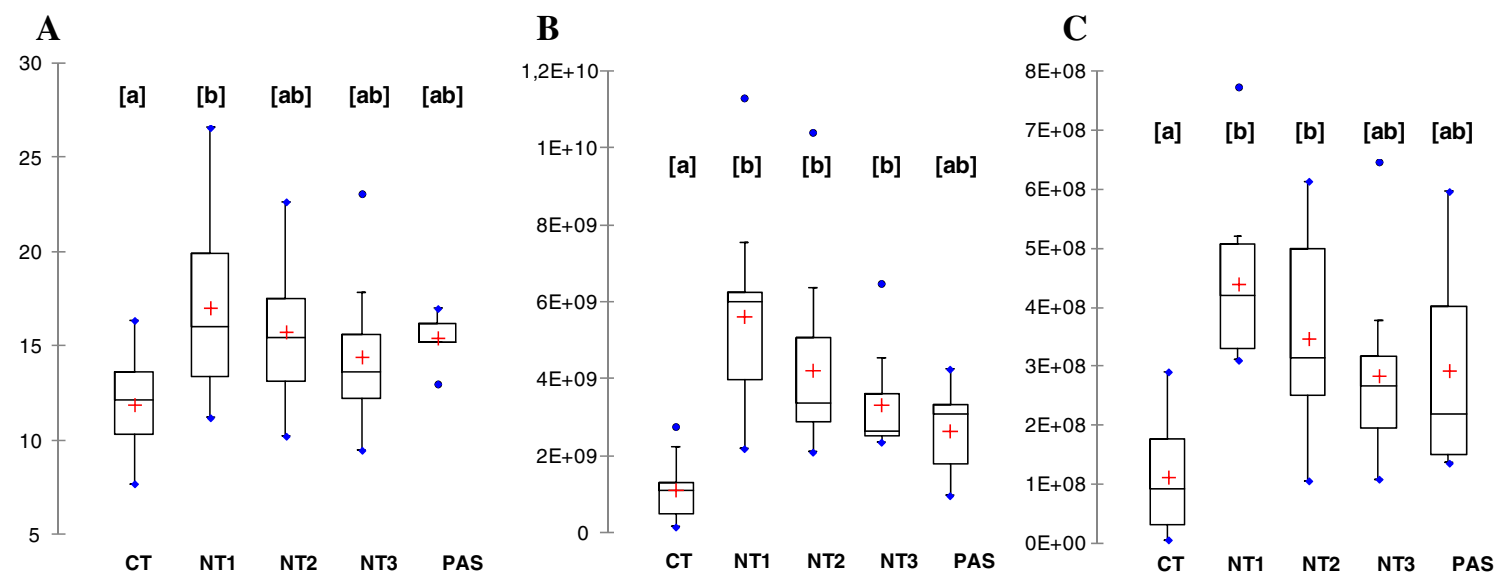

Fig. 3 Top soil (0-10 $\mathrm{cm}$ layer) box and whisker representation of a molecular biomass (in micrograms of DNA per gram of soil), $\mathbf{b}$ bacterial density (copy of 16S rDNA per gram of soil), and $\mathbf{c}$ fungal density (copy of $18 \mathrm{~S}$ rDNA per gram of soil; 52 plots) recorded in PAS, natural pastureland; $C T$ conventional tillage, and $N T(1,2$, and 3$)$ notill systems. The first (Q1), median, and third (Q3) quartiles are

indicated by the bottom, the central, and the top line of the box, respectively. The bottom whisker extends to the lowest value of the data set, while the top whisker extends to the highest one. Outliers are indicated by points. Letters in brackets indicate significant differences according to Kruskal-Wallis test $(P<0.05)$, Bonferroni correction 
situations, SOC and nitrogen content, $\mathrm{CEC}$, and $\mathrm{pH}$ have been reported as important parameters influencing microbial biomass (Martiny et al. 2006; Lejon et al. 2007; Dequiedt et al. 2011). Finally, microbial biomass might be more discriminated by other factors than those monitored. Tillage affects soil temperature and humidity which in turn strongly influence soil microbial biomass (Frey et al. 1999; Spedding et al. 2004), and could explain the lowest microbial biomass observed in tilled system.

The number of copies of $16 \mathrm{~S}$ rDNA and $18 \mathrm{~S}$ rDNA, which were used as estimates of bacterial and fungal molecular densities, respectively, decreased significantly along the gradient NT1 and NT2 $>$ NT3 and PAS $>$ CT (Fig. 3b, c). After 2 years of cultivation, bacterial and fungal densities were respectively five- and fourfold higher under NT1 than under CT, confirming the high sensitivity and reactivity of these communities to land use management and soil environmental changes (Frey et al. 1999; Lauber et al. 2008; Rousk et al. 2010).

Tillage appears to be a major factor influencing both bacterial and fungal densities with main significant differences observed between tilled (CT) and no-tilled (NTs and PAS) treatments (Fig. 3b, c). Tillage induced a decrease in SOC (Table 1), this latter being positively correlated with bacterial density (Fig. 2). Similarly, tillage induced a reduction of soil aggregate stability and soil macroaggregate content (Table 1), which was also positively correlated with both fungal and bacterial densities (Fig. 2), confirming the importance of macroaggregates as microhabitat for microorganisms (Ranjard and Richaume 2001). In addition, tillage has been demonstrated to affect soil temperature and humidity (Frey et al. 1999), which in turn strongly influence soil microbial abundance and in particular fungal development (Frey et al. 1999; Spedding et al. 2004). Finally, tillage causes direct tissue damage to the fungi leading to a reduction in their abundance at soil surface (Balesdent et al. 2000; Six et al. 2002).

Crop residue diversity appeared as the second main factor influencing both bacterial and fungal densities since the numbers of copies of $16 \mathrm{~S}$ rDNA and $18 \mathrm{~S}$ rDNA were significantly and positively correlated with the percentage of broad-leaf species in stubble returns (Fig. 2). The gradient observed regarding the diversity of crop residues, with about $20 \%$ broad-leaf species in restitutions for NT1 and NT2 versus less than $5 \%$ for NT3 and PAS (Table 1), fits with the differences in bacterial and fungal densities observed among no-tilled treatments (Fig. 3b, c). Finally, bacterial density also appeared to be influenced by other trophic parameters with significant and positive correlations found in the total amount of stubble returns and soil exchangeable base content (Fig. 2).

In comparison to the natural pastureland (PAS), the higher amount of stubble returns and soil exchangeable base content (Table 1) under no-till systems (NTs) might help explain the difference in bacterial density observed between NTs and PAS (Fig. 3b). Altogether, our results highlighted the different processes driving soil bacterial and fungal density changes: bacterial density mainly appeared to be influenced by trophic factors (e.g., diversity and quantity of crop residues, SOC, and sum of exchangeable bases), while fungal density appeared to be influenced by both trophic (e.g., diversity of crop residues) and atrophic factors (e.g., direct tissue damage by tilling tools and soil moisture content).

We did not find any significant difference in the fungal to bacterial (F/B) ratio among treatments (data not shown). F/B ratio is a widely used metric tool to assess the impact of environmental change on soil microbial community structure and functioning (Strickland and Rousk 2009). Our results are not in agreement with Kladivko (2001) who proposed that notill systems (NTs) would result in a fungal-dominated system instead of the bacterial-dominated system expected under conventional tillage practices. Several studies reported an increase in $\mathrm{F} / \mathrm{B}$ ratio due to a higher response of fungal biomass to increased soil moisture under NTs (e.g., Frey et al. 1999; Spedding et al. 2004) and/or to the suppression of hyphal growth disturbance by tillage (Frey et al. 1999; Balesdent et al. 2000). On the other hand, our results are in agreement with the review of Strickland and Rousk (2009) who reported empirical evidence in support of such impacts on F/B dominance are still far from generic.

\subsection{Early effect on soil bacterial genetic structure}

Using principal component analysis with between-group analysis performed on B-ARISA fingerprints, we found four discriminated genetic structure of indigenous bacterial communities under: (1) NT3, (2) NT1 and NT2, (3) CT, and (4) PAS (Fig. 4a), with these four classes being significantly different according to the Monte Carlo test $(1,000$ permutations, $p$ value $<0.001)$. A higher discrimination in bacterial communities was observed between non-cultivated and cultivated plots, discriminated on the first axis, than between agricultural treatments, discriminated on the second axis. This distinction between non-cultivated and cultivated soil might increase in the coming years since Buckley and Schmidt (2001) reported higher microbial community structural differences between cultivated and never-cultivated soils, than between cultivated soils showing different cultivation and plant community histories. The low but significant differences in bacterial genetic structure observed between NTs and CT might be related to the limited duration of cultivation (2 years) at evaluation.

Using coinertia analysis between B-ARISA fingerprints and physicochemical parameters, we found that the main 


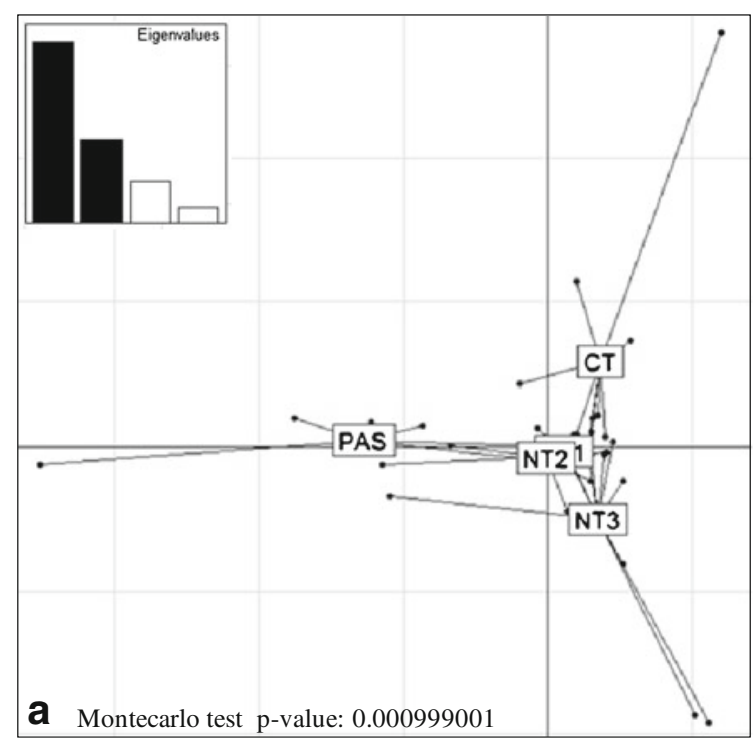

Fig. 4 Factorial maps of: a bacterial community genetic structure (principal component analysis of B-ARISA fingerprints, betweengroup analysis). b Correlation circle of the coinertia analysis performed between the PCA of B-RISA fingerprints and the PCA of soil physicochemical characteristics (52 plots). PAS natural pastureland, $C T$ conventional tillage, $N T(1,2$, and 3$)$ no-till systems. SOC soil organic

factors influencing the bacterial genetic structural changes among land use managements (Fig. 4b) were different from those influencing microbial abundance. The first axis of the coinertia factorial map (PC1) showed a significant difference (Monte Carlo test $p$ value $<0.001$ ) between noncultivated and cultivated plots according to soil exchangeable $\mathrm{Al}$ and available phosphorus (P), with the structure of the bacterial communities under PAS appearing strongly related to high $\mathrm{Al}$ content. The second axis of the factorial map showed an ordination of cultivated soils according to soil $\mathrm{pH}$, nutrient content (CEC, total exchangeable bases), the mean weight diameter (MWD) of aggregates, and soil carbon to nitrogen $(\mathrm{C} / \mathrm{N})$ ratio. The early changes in bacterial genetic structure under NT3 were related to an increase in $\mathrm{pH}$, nutrient availability, and MWD as compared to NT1, NT2, and CT (Table 1). By contrast, the early changes observed under CT were more related to a decrease in $\mathrm{pH}$, nutrient availability, MWD and an increase in $\mathrm{C} / \mathrm{N}$ ratio (Table 1).

Our results are in agreement with several studies that describe $\mathrm{pH}$ as the main discriminating factor of bacterial diversity (Grayston et al. 2004; Martiny et al. 2006; Fierer et al. 2009). Variations of $\mathrm{C} / \mathrm{N}$ ratios have been shown to explain shifts in F/B ratio (Fierer et al. 2009) and bacterial genetic structure in vineyard soils (Lejon et al. 2007). However, no reference was found regarding the effect of soil available $\mathrm{P}, \mathrm{Al}$ content, and/or CEC changes on bacterial genetic structure. While we show that the quality of crop residues strongly influenced bacterial abundance, this factor

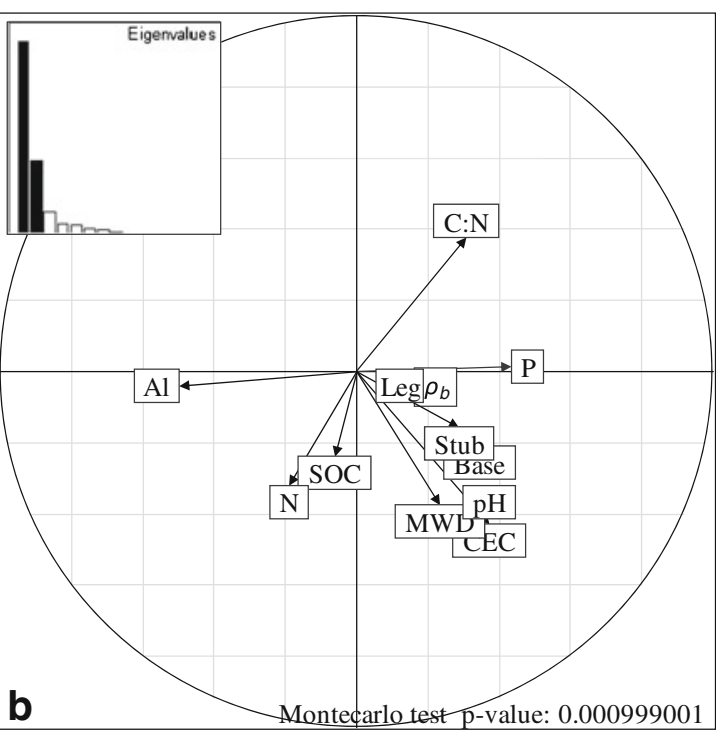

carbon, $N$ total nitrogen, $C: N$ carbon to nitrogen ratio, $P$ available phosphorus, Base sum of exchangeable bases, $A l$ exchangeable aluminum, $C E C$ cation exchange capacity, $\rho_{b}$ bulk density, $M W D$ mean weight diameter, Stub cumulated amount of stubble returns, Leg percentage of broad-leaf species in Stub

did not appear influent regarding bacterial community structural changes, contrary to other studies (Nicolardot et al. 2007; Pascault et al. 2010). Finally, tillage could partly explain the differences in bacterial genetic structure observed between conservation (NTs) and conventional (CT) cropping systems, by modifying microbial access to crop residues and soil moisture content (Nicolardot et al. 2007).

\section{Conclusion}

In an acid tropical grassland environment, our results show that no-till (NTs) and conventional tillage (CT) farming systems both induced early but different modifications in top soil properties in reference to the natural pasture (PAS): NTs increased aggregate stability and soil organic carbon content, enhanced nutrient availability and microbial biomass as a result of a simultaneous increase of fungal and bacterial densities. We also showed a significant discrimination of soil microbial community structures between NTs, $\mathrm{CT}$, and PAS. In addition, bacterial abundance and diversity appeared to be differently driven by soil environment changes: bacterial density was affected by the quantity and diversity of crop residues, soil organic carbon, and exchangeable base content, whereas soil bacterial genetic structure was influenced by soil exchangeable $\mathrm{Al}$ content, $\mathrm{pH}, \mathrm{CEC}$, and soil $\mathrm{C} / \mathrm{N}$ ratio, all these parameters being affected by tillage, residue management, and soil organic and inorganic amendments. As an application of our results, 
we recommend no-till systems with high residue restitutions and lime amendment in order to improve the physical, chemical, and microbial properties of tropical acid soils, and thus contribute to the sustainability of agricultural systems.

Acknowledgments The authors would like to thank the SectorBased Program in Agroecology (PROSA), the French Development Agency (AFD), the French Global Environment Facility (FFEM), and the French Ministry of Foreign Affairs for their financial support. We would also like to thank the Department of Agriculture and Forestry of Xieng Khouang Province and the National Agriculture and Forestry Research Institute for their technical support, along with Mrs. Cécile Fovet-Rabot for her comments.

Open Access This article is distributed under the terms of the Creative Commons Attribution License which permits any use, distribution, and reproduction in any medium, provided the original author(s) and the source are credited.

\section{References}

Balesdent J, Chenu C, Balabane M (2000) Relationship of soil organic matter dynamics to physical protection and tillage. Soil Till Res 53:215-230

Bossuyt H, Denef K, Six J, Frey SD, Merckx R, Paustian K (2001) Influence of microbial populations and residue quality on aggregate stability. Appl Soil Ecol 16:195-208. doi:10.1016/s09291393(00)00116-5

Buckley DH, Schmidt TM (2001) The structure of microbial communities in soil and the lasting impact of cultivation. Microb Ecol 42:11-21

Bunemann EK, Schwenke GD, Van Zwieten L (2006) Impact of agricultural inputs on soil organisms - a review. Aust J Soil Rer 44:379-406. doi:10.1071/sr05125

Castro Filho C, Lourenço A, Guimarãesde MF, Fonseca ICB (2002) Aggregate stability under different management systems in a red Latosol in the State of Paraná, Brasil. Soil Till Res 65:45-51

Chemidlin Prevost-Boure N, Christen R, Dequiedt S, Mougel C, Lelievre M, Jolivet C, Shahbazkia HR, Guillou L, Arrouays D, Ranjard L (2011) Validation and application of a PCR primer set to quantify fungal communities in the soil environment by realtime quantitative PCR. PLoS One 6:e24166

Dequiedt S, Saby NPA, Lelievre M, Jolivet C, Thioulouse J, Toutain B, Arrouays D, Bispo A, Lemanceau P, Ranjard L (2011) Biogeographical patterns of soil molecular microbial biomass as influenced by soil characteristics and management. Global Ecol Biogeogr 20:641-652. doi:10.1111/j.1466-8238.2010.00628.x

Derpsch R, Friedrich T, Kassam A, Hongwen L (2010) Current status of adoption of no-till farming in the world and some of its main benefits. Int J Agr Biol Eng 3:1-25

Dick RP (1992) A review: long-term effects of agricultural systems on soil biochemical and microbial parameters. Agr Ecosyst Environ 40:25-36

Fierer N, Strickland MS, Liptzin D, Bradford MA, Cleveland CC (2009) Global patterns in belowground communities. Ecol Lett 12:1238-1249. doi:10.1111/j.1461-0248.2009.01360.x

Frey SD, Elliott ET, Paustian K (1999) Bacterial and fungal abundance and biomass in conventional and no-tillage agroecosystems along two climatic gradients. Soil Biol Biochem 31:573-585. doi:10.1016/s0038-0717(98)00161-8
Grayston SJ, Campbell CD, Bardgett RD, Mawdsley JL, Clegg CD, Ritz K, Griffiths BS, Rodwell JS, Edwards SJ, Davies WJ, Elston DJ, Millard P (2004) Assessing shifts in microbial community structure across a range of grasslands of differing management intensity using CLPP, PLFA and community DNA techniques. Appl Soil Ecol 25:63-84. doi:10.1016/s0929-1393(03)00098-2

IAEA (2000) Management and conservation of tropical acid soils for sustainable crop production. IAEA, Vienna, IAEA-TECDOC1159; ISSN 1011-4289

Kaschuk G, Alberton O, Hungria M (2010) Three decades of soil microbial biomass studies in Brazilian ecosystems: lessons learned about soil quality and indications for improving sustainability. Soil Biol Biochem 42:1-13. doi:10.1016/j.soilbio.2009.08.020

Kladivko EJ (2001) Tillage systems and soil ecology. Soil Till Res 61:61-76. doi:10.1016/s0167-1987(01)00179-9

Lal R (2008) Soils and sustainable agriculture. A review. Agron Sustain Dev 28:57-64. doi:10.1051/agro:2007025

Lauber CL, Strickland MS, Bradford MA, Fierer N (2008) The influence of soil properties on the structure of bacterial and fungal communities across land-use types. Soil Biol Bioch 40(9):2407-2415. doi:10.1016/j.soilbio.2008.05.021

Lejon DPH, Sebastia J, Lamy I, Chaussod R, Ranjard L (2007) Relationships between soil organic status and microbial community density and genetic structure in two agricultural soils submitted to various types of organic management. Microb Ecol 53:650-663. doi:10.1007/s00248-006-9145-6

Maron PA, Mougel C, Ranjard L (2011) Soil microbial diversity: methodological strategy, spatial overview and functional interest. CR Biol 334:403-411. doi:10.1016/j.crvi.2010.12.003

Marstorp H, Guan X, Gong P (2000) Relationship between dsDNA, chloroform labile $\mathrm{C}$ and ergosterol in soils of different organic matter contents and $\mathrm{pH}$. Soil Biol Biochem 32:879-882. doi:10.1016/s0038-0717(99)00210-2

Martiny JBH, Bohannan BJM, Brown JH, Colwell RK, Fuhrman JA, Green JL, Horner-Devine MC, Kane M, Krumins JA, Kuske CR, Morin PJ, Naeem S, Ovreas L, Reysenbach AL, Smith VH, Staley JT (2006) Microbial biogeography: putting microorganisms on the map. Nat Rev Microbiol 4:102-112. doi:10.1038/nrmicro1341

Nicolardot B, Bouziri L, Bastian F, Ranjard L (2007) Influence of location and quality of plant residues on residue decomposition and genetic structure of soil microbial communities. Soil Biol Biochem 39:1631-1644. doi:10.1016/j.soilbio.2007.01.012

Pascault N, Nicolardot B, Bastian F, Thiebeau P, Ranjard L, Maron PA (2010) In situ dynamics and spatial heterogeneity of soil bacterial communities under different crop residue management. Microb Ecol 60:291-303. doi:10.1007/s00248-010-9648-z

Ranjard L, Richaume A (2001) Quantitative and qualitative microscale distribution of bacteria in soil. Res Microbiol 152(8):707-716. doi:10.1016/s0923-2508(01)01251-7

Ranjard L, Lejon DPH, Mougel C, Schehrer L, Merdinoglu D, Chaussod R (2003) Sampling strategy in molecular microbial ecology: influence of soil sample size on DNA fingerprinting analysis of fungal and bacterial communities. Environ Microbiol 5:1111-1120. doi:10.1046/j.1462-2920.2003.00521.x

Rousk J, Baath E, Brookes PC, Lauber CL, Lozupone C, Caporaso JG, Knight R, Fierer N (2010) Soil bacterial and fungal communities across a $\mathrm{pH}$ gradient in an arable soil. ISME J 4:1340-1351. doi:10.1038/ismej.2010.58

Sapkota T, Mazzoncini M, Bàrberi P, Antichi D, Silvestri N (2011) Fifteen years of no till increase soil organic matter, microbial biomass and arthropod diversity in cover crop-based arable cropping systems. Agron Sustain Dev. doi:10.1007/s13593-011-0079-0

Séguy L, Bouzinac S, Husson O (2006) Direct-seeded tropical soil systems with permanent soil cover: Learning from Brazilian experience. In: Uphoff N, Ball AS, Fernandes E, Herren H, Husson O, Laing M, Palm C, Pretty J, Sanchez P (eds) Biological 
approach to sustainable soil systems. CRC Press, Taylor \& Francis, pp 323-342

Six J, Feller C, Denef K, Ogle SM, Sa JCD, Albrecht A (2002) Soil organic matter, biota and aggregation in temperate and tropical soils - effects of no-tillage. Agronomie 22:755-775. doi:10.1051/ agro:2002043

Smith CJ, Osborn AM (2009) Advantages and limitations of quantitative PCR (Q-PCR)-based approaches in microbial ecology. FEMS Microbiol Ecol 67(1):6-20. doi:10.1111/j.15746941.2008.00629.x
Spedding TA, Hamel C, Mehuys GR, Madramootoo CA (2004) Soil microbial dynamics in maize-growing soil under different tillage and residue management systems. Soil Biol Biochem 36:499512. doi:10.1016/j.soilbio.2003.10.026

Strickland MS, Rousk J (2009) Considering fungal:bacterial dominance in soils - methods, controls, and ecosystem implications. Soil Biol Biochem 42:1385-1395. doi:10.1016/j.soilbio.2010.05.007

Thioulouse J, Chessel D, Dolédec S, Olivier JM (1997) Ade-4: a multivariate analysis and graphical display software. Stat Comput $7: 75-83$ 